\title{
Liposomal Encapsulation of Silver Nanoparticles Enhances Cytotoxicity and Causes Induction of Reactive Oxygen Species- Independent Apoptosis
}

\author{
Azeez Yusuf \\ Technological University Dublin, Dublin, Ireland \\ A. Brophy \\ Technological University Dublin, Dublin, Ireland \\ Brian Gorey \\ Technological University Dublin
}

See next page for additional authors

Follow this and additional works at: https://arrow.tudublin.ie/sciendoc

Part of the Nanotechnology Commons

\section{Recommended Citation}

Yusef, A., Brophy, A. \& Gorey, B. (2017). Liposomal encapsulation of silver nanoparticles enhances cytoxicity and causes induction of reactive oxygen species-independentj apoptosis. Journal of Applied Toxocology, vol 38, no. 5, pg. 616-627. doi: 10.1002/jat.3566

This Article is brought to you for free and open access by the Science at ARROW@TU Dublin. It has been accepted for inclusion in Doctoral by an authorized administrator of ARROW@TU Dublin. For more information, please contact arrow.admin@tudublin.ie, aisling.coyne@tudublin.ie,gerard.connolly@tudublin.ie.

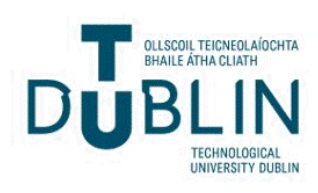


Authors

Azeez Yusuf, A. Brophy, Brian Gorey, and Alan Casey

This article is available at ARROW@TU Dublin: https://arrow.tudublin.ie/sciendoc/208 


\title{
Liposomal encapsulation of silver nanoparticles enhances cytotoxicity and causes induction of reactive oxygen species- independent apoptosis
}

\author{
A. Yusuf ${ }^{1,2}$ \\ | A. Brophy ${ }^{2}$ | \\ B. Gorey ${ }^{2}$ । \\ A. Casey ${ }^{1,2}$
}

${ }^{1}$ School of Physics, Dublin Institute of Technology, Kevin Street, Dublin 8, Ireland

${ }^{2}$ Nanolab Research Centre, FOCAS Research Institute, Dublin Institute of Technology, Kevin Street, Dublin 8, Ireland

Correspondence

Azeez Yusuf, School of Physics, Dublin Institute of Technology, Kevin Street, Dublin 8, Ireland.

Email: d15127628@mydit.ie

\section{Funding information}

Science Foundation Ireland, Grant/Award Number: 11/PI/1108; Fiosraigh Dean of Graduate Award, Dublin Institute of Technology

\begin{abstract}
Silver nanoparticles (AgNP) are one of the most widely investigated metallic NPs due to their promising antibacterial activities. In recent years, AgNP research has shifted beyond antimicrobial use to potential applications in the medical arena. This shift coupled with the extensive commercial applications of AgNP will further increase human exposure and the subsequent risk of adverse effects that may result from repeated exposures and inefficient delivery, meaning research into improved AgNP delivery is of paramount importance. In this study, AgNP were encapsulated in a natural biosurfactant, dipalmitoylphosphatidylcholine, in an attempt to enhance the intracellular delivery and simultaneously mediate the associated cytotoxicity of the AgNP. It was noted that because of the encapsulation, liposomal AgNP (Lipo-AgNP) at $0.625 \mu \mathrm{g} \mathrm{m}{ }^{-1}$ induced significant cell death in THP1 cell lines a notably lower dose than that of the uncoated AgNP induced cytotoxicity. The induced cytotoxicity was shown to result in an increased level of DNA fragmentation resulting in a cell cycle interruption at the $\mathrm{S}$ phase. It was shown that the predominate form of cell death upon exposure to both uncoated AgNP and Lipo-AgNP was apoptosis. However, a reactive oxygen species-independent activation of the executioner caspases 3/7 occurred when exposed to the Lipo-AgNP. These findings showed that encapsulation of AgNP enhance AgNP cytotoxicity and mediates a reactive oxygen species-independent induction of apoptosis.
\end{abstract}

\section{KEYWORDS}

AgNP encapsulation, cytotoxicity, DNA fragmentation, liposome, silver nanoparticle (AgNP)

\section{1 | INTRODUCTION}

Silver nanoparticles (AgNP) are one of the most crucial metals in nanomedicine/nanotechnology. They have been investigated in the treatment of bacterial diseases and are found to possess a striking antimicrobial activity. AgNP are known to cause oxidative lesion that destroys the bacterial cell wall, facilitating its entry into the cell to bind to sulfhydryl groups of key proteins and bacterial DNA to disrupt crucial metabolic processes and halt cell proliferation (Feng et al., 2000; Grigor'eva et al., 2013; Wigginton et al., 2010). This has also led to the worldwide commercialization of AgNP in an array of formats with up to $24 \%$ of nanotechnology driven everyday consumer products worldwide containing AgNP (Vance et al., 2015). Some of the AgNP-based consumable products include but are not limited to food packaging, antibacterial creams, coatings in antimicrobial textiles and domestic cleaning products. AgNP are widely used in medicine for dressing wounds, in making orthodontic materials, coating of bone prosthesis, coating of stents or catheters, cleaning surgical equipment and in certain contraceptive devices (Blaske et al., 2013; Correa et al., 2015; Knetsch \& Koole, 2011; Samuel \& Guggenbichler, 2004). In recent years, research involving AgNP has moved beyond investigating its antibacterial properties. The possibility of AgNP as an anticancer drug has been the subject of research due to the emergence of drug-resistant cancer cells and the discovery that AgNP possess an inherent cytotoxic effect on cancer cells (Zhang, Liu, Shen, \& Gurunathan, 2016).

With increasing applications of AgNP in consumable products and in medicine there is an increased risk of exposure to the toxic side effects of AgNP that may have leached into the environment. Benn and Westerhoff (2008) showed that a sock coated with about $1.36 \mathrm{mg}$ of $\mathrm{AgNP}$ can release $48 \%$ of its coating into water by simply 
shaking the sock in water or as much as $100 \%$ in four consecutive washes. AgNP can also be released in the same manner from shampoos, toothpaste, detergents and medical apparels (Benn, Cavanagh, Hristovski, Posner, \& Westerhoff, 2010). It has been reported that AgNP route of entry could be through oral, pulmonary or dermal routes. Irrespective of the entry route, AgNP induced cell death through the generation of reactive oxygen species (ROS), increased DNA damage and impairment of mitochondrial functions (Kang, Jung, \& Lim, 2012). As such, continuous use of AgNP at these high concentrations comes with a potential danger in the near future. For instance, inefficient delivery of AgNP to target cells could result in systemic toxicity as it has been previously reported that prolonged biodistribution of AgNP could result in systemic transport to different tissues particularly to the spleen and liver (Xue et al., 2012). As such, devising ways by which low concentrations of AgNP can be efficiently delivered to target cells thus becomes pertinent. Generally, the unspecific systemic activities of conventional anticancer drugs are the major limiting factor in their application as chemotherapeutics. To subvert this negative side effect, encapsulation of drugs in a lipid bilayer has been investigated for improved delivery with promising results (Sercombe et al., 2015). For example, doxorubicin is a potent anticancer drug that inhibits topoisomerase II preventing accessibility of DNA polymerase to the DNA. Regardless of its potency, there is limitation to the use of doxorubicin in cancer treatment due to the negative side effects following its administration such as alopecia, hepatotoxicity, cardiotoxicity and nephrotoxicity (Tacar, Sriamornsak, \& Dass, 2013). However, liposomal encapsulation of doxorubicin has been shown to improve its delivery in addition to alleviating the negative side effects of the drug, reducing the required concentration to achieve cell death (Brown \& Khan, 2012; Camacho et al., 2016; Souto et al., 2016).

Liposomes like many other NPs have unique characteristics that make them efficient drug delivery vehicles. They are suitable for transporting both hydrophobic and hydrophilic molecules; the lipid layer of liposomes can entrap hydrophobic drugs due to hydrophobic interactions between the fatty acid chains and the drug while the aqueous core of the liposome can also hold hydrophilic drugs (Bozzuto \& Molinari, 2015). In general, liposomes are often prepared from phospholipids, which then form the outer layer of the nanostructure that can be similar to the lipid bilayer of the cell membrane. The lipid layer of liposomes aids the passive transport of the liposome and its associated content into the cell. This prevents the requirement of membrane channels or pumps normally controlling the entry of charged or polar molecules such as peptides, metals and synthetic compounds that can be encapsulated in the lipid vesicle. These attributes allow for dose intensification of compounds that are encapsulated within the liposome while limiting any negative side effects associated with excess free drug present in a non-liposome delivery method (Silverman, Reynolds, \& Deitcher, 2013). Liposomes have controllable sizes and their surface properties are easily modified in the synthesis process and can be tailored to any functional delivery requirements. These properties coupled with an enhanced permeability and retention effect in vivo, increases their ability to accumulate in a tumour microenvironment, which is typically composed of leaky vessels and abnormal cell junctions (Nehoff, Parayath, Domanovitch, Taurin, \& Greish, 2014; Xing, Hwang, \& Lu, 2016).
In this study, AgNP were encapsulated in a liposome made of natural biosurfactant, dipalmitoyl phosphatidylcholine (DPPC) to improve delivery due to increased permeabilization into the target cells. It is hoped that such a system will not only reduce the non-specific cytotoxic effect observed during AgNP treatment, but it may also reduce the concentration of AgNP required to elicit the expected cytotoxic response. Subsequently, this may help reduce the development of resistant strains to AgNP-based drug as well as eliminate the release of AgNP in large quantities into the ecosystem.

\section{2 | MATERIALS AND METHODS}

\section{1 | Materials and reagents}

Silver nitrate $\left(\mathrm{AgNO}_{3}\right)$ (CAS no.: 7761-88-8), sodium borohydride $\left(\mathrm{NaBH}_{4}\right.$ ) (CAS no.: 16940-66-2), DPPC (CAS no.: 63-89-8), cholesterol (CAS no.: 57-88-5), propidium iodide (PI) (CAS no.: 25535-16-4) and sodium azide $\left(\mathrm{NAN}_{3}\right.$ ) (CAS no.: 26628-22-8) were all purchased from Sigma-Aldrich, Dublin, Ireland. All tissue culture plastics, 96-well plates, T75 and T25 flasks were purchased from Thermo Fisher Scientific, Dublin, Ireland. Alamar blue (catalogue no. DAL1025), 6-carboxy-2',7'dichlorofluorescein diacetate (carboxy-DCFDA dye; catalogue no. C400) and CellEvent Caspase-3/7 Green Detection Reagent and SYTOX AADvanced Dead Cell Stain (catalogue no. C10740) Calcein-AM dye (lot no. 1475337) were all purchased from Life Technologies, through Biosciences Ltd., Dublin, Ireland.

\section{2 | Silver nanoparticle synthesis}

AgNPs were produced by a borohydride reduction of silver nitrate as detailed in Equation 1 below,

$$
\mathrm{AgNO}_{3(\mathrm{aq})}+\mathrm{NaBH}_{4(\mathrm{aq})} \rightarrow \mathrm{Ag}_{(\mathrm{s})}^{0}+1 / 2 \mathrm{~B}_{2} \mathrm{H}_{6(\mathrm{~g})}+1 / 2 \mathrm{H}_{2(\mathrm{~g})}+\mathrm{NaNO}_{3(\mathrm{aq})}
$$

Briefly, a $1 \mathrm{~mm}$ solution of $\mathrm{AgNO}_{3}$ and $2 \mathrm{mM}$ solution of $\mathrm{NaBH}_{4}$ were prepared in ultrapure grade distilled water. To prevent agglomeration of the AgNP during the reduction process, the reaction was carried out at low temperature; $30 \mathrm{ml}$ of $\mathrm{NaBH}_{4}$ was added to an Erlenmeyer flask placed in an ice bath and stirred at $350 \mathrm{rpm}$ for 30 minutes to equilibrate. At a drop per second rate, $6 \mathrm{ml}$ of $\mathrm{AgNO}_{3}$ was added to the $\mathrm{NaBH}_{4}$ solution under constant stirring. After all the $\mathrm{AgNO}_{3}$ had been added, the stirring was stopped and the flask taken out of the ice bath. To prevent further agglomeration of the AgNP the solution was placed back on the stirrer and stirred until room temperature was achieved. The resulting golden yellow solution was stable at $4^{\circ} \mathrm{C}$.

\subsection{X-ray diffraction and energy dispersive X-ray analysis of silver nanoparticle}

Powdered X-ray diffraction (XRD) characterization of AgNP was conducted with a Philips diffractometer (Philips Inc., Westborough, USA) using a monochromatic $\mathrm{Cu}-\mathrm{Ka}_{1}$ radiation source $(\lambda=1.5406 \AA)$ operated at $40 \mathrm{keV}, 30 \mathrm{~mA}$ and a $2 \theta$ angle pattern. The scanning was carried out in the $20^{\circ}$ to $80^{\circ}$ region and the crystalline structure was analysed by comparing the obtained result with that of the Joint 
Committee on Powder Diffraction Standards library. Energy dispersive X-ray of AgNP was carried out by drop casting $100 \mu \mathrm{l}$ of AgNP on a silicon (Si) wafer and analysed using a Hitachi SU-70 (Hitachi, Tokyo, Japan) Oxford Instruments $50 \mathrm{~mm}^{2} \mathrm{X}$-Max silicon drift EDS detector operated at $20 \mathrm{keV}$.

\section{4 | Liposome preparation and encapsulation of silver nanoparticle}

Liposomes were prepared with a combination of DPPC and cholesterol via modification of a dehydration-rehydration technique originally reported by Mugabe, Azghani, and Omri (2006). Initially, DPPC and cholesterol were dissolved in $5 \mathrm{ml}$ chloroform and the solution was mixed until clear. It was then dried in a vacuum oven at $52^{\circ} \mathrm{C}$ overnight (above melting temperature of DPPC). The resultant lipid cake was rehydrated in distilled deionized water $\left(\mathrm{ddH}_{2} \mathrm{O}\right)$ at $60^{\circ} \mathrm{C}$ in a shaker. After the lipid was rehydrated, an AgNP solution was added to make a final lipid concentration of $1 \mathrm{mg} \mathrm{ml}^{-1}$ of DPPC and $0.23 \mathrm{mg} \mathrm{ml}^{-1}$ of cholesterol to give a 7:3 molar ratio (Briuglia, Rotella, McFarlane, \& Lamprou, 2015). The solution was then placed in the shaker at $60^{\circ} \mathrm{C}$ for another 20 minutes after which it was vortexed and extruded through a $100 \mathrm{~nm}$ Nanosizer polycarbonate extruder (TTScientific, Knoxville, USA). The resulting colloidal mixture was stored at $4{ }^{\circ} \mathrm{C}$ before use.

\section{5 | Estimating encapsulation efficiency of the liposome}

To estimate the encapsulation efficiency, Lipo-AgNP were centrifuged at $30000 \mathrm{~g}$ for 1 hour and the supernatant harvested. The supernatant was then analysed by atomic absorption spectrophotometry to estimate the concentration of silver in the solution. The encapsulation efficiency $(E)$ of the liposome was then calculated using the formula below:

$$
E=\frac{\text { Total AgNP added to liposome-AgNP in supernatant }}{\text { Total AgNP added to liposome }} \times 100
$$

\section{6 | Scanning and scanning transmission electron micrograph analysis}

Scanning electron micrograph (SEM) micrographs were obtained for all AgNP and liposomal AgNP (Lipo-AgNP) using a Hitachi SU-6600 field emission SEM (Hitachi, Maidenhead, UK) at an accelerating voltage of $25 \mathrm{kV}$ and working distance of $8 \mathrm{~mm}$. Before SEM analysis, $5 \mu \mathrm{l}$ of each sample was drop-cast on to a $5 \times 5 \mathrm{~mm}$ pure silicon wafer substrate (Ted Pella Inc., Redding, California, USA) 24 hours before obtaining micrographs and allowed to air dry. Before scanning transmission electron micrograph (STEM) analysis, $3 \mu \mathrm{l}$ of each sample was drop-cast on to a carbon formvar copper grid (Agar Scientific Ltd., Stanstead, UK) 24 hours before obtaining micrographs and allowed to air dry.

\section{7 | Cell culture and exposure}

THP1 (ATCC $\left(\right.$ ) TIB-202 ${ }^{\text {TM }}$ ) a suspension line derived from a human peripheral blood monocyte from an acute monocytic leukaemia patient, was used for this study. THP1 cells were cultured in RPMI-
1640 media containing $2 \mathrm{mM}$ L-glutamine (Sigma-Aldrich) supplemented with $10 \%$ fetal bovine serum and incubated at $37^{\circ} \mathrm{C}, 95 \%$ humidity and $5 \% \mathrm{CO}_{2}$.

For particle exposure, cells were seeded in to a 96-well plate at a density of $1 \times 10^{4}$ cells in $100 \mu$ l of culture media for a 24 and 48 hour time period. A minimum of three independent experiments were conducted and for each independent experiment, six replicate wells were employed per concentration per plate. The cells were then treated with un-encapsulated (AgNP) and Lipo-AgNP after seeding. A positive kill control, a $10 \%(\mathrm{v} / \mathrm{v})$ dimethyl sulfoxide solution was prepared in serum-free media to treat the cells while a negative control of unexposed cells was also incorporated on to the plate for both AgNP- and Lipo-AgNP-exposed cells. An additional positive control was performed for THP1 cells exposed to $0.325-5 \mu \mathrm{g} \mathrm{ml}^{-1} \mathrm{Ag}^{+}$solution, prepared by dissolving corresponding amount of $\mathrm{AgNO}_{3}$ in $\mathrm{ddH}_{2} \mathrm{O}$, to test the possible influence of $\mathrm{AgNP}$ ionization into $\mathrm{Ag}^{+}$on its cytotoxic effect.

\section{8 | Cell viability}

Cellular viability was evaluated with the Alamar Blue assay (AB). Briefly, a $10 \%(v / v) A B$ solution in serum-free media was prepared and kept warm in a water bath at $37^{\circ} \mathrm{C}$. The plate containing treated cells was centrifuged in a Heraeus Megafuge 16R (Thermo Fisher) at $500 \mathrm{~g}$ and $20^{\circ} \mathrm{C}$ for 5 minutes and the exposure media removed after which $100 \mu$ l of the $10 \%$ AB solution was added to each well. The plates were then incubated for 3 hours after which the resulting fluorescence of the converted $A B$ dye was measured at 540 and $595 \mathrm{~nm}$ excitation and emission wavelengths respectively using SpectraMax ${ }^{\circledR}$ M3 MultiMode Microplate Reader and compared to the relative controls.

\section{9 | Reactive oxygen species assay}

ROS generation in the THP1 cells because of particle exposure was measured with a carboxy-DCFDA assay. In the assay carboxy-DCFDA a non-fluorescent dye is metabolized by esterase into $\mathrm{H}_{2}$ DCFDA, which is further oxidized by ROS generated in the cell to a green fluorescent DCFDA dye. To quantify ROS generation, the THP1 cells were seeded into a T75 flask at $5 \times 10^{5}$ cells ml $^{-1}$ in RPMI media containing $2 \%$ fetal bovine serum and the cells were loaded with $10 \mu \mathrm{M}$ of carboxy-DCFDA dye and incubated for 30 minutes under normal culture condition. The loaded cells were then centrifuged at $300 \mathrm{~g}$ for $5 \mathrm{~min}$ and the medium containing excess carboxy-DCFDA was removed. The loaded cells were then washed twice in warm sterile phosphate-buffered saline (PBS) and then re-suspended in normal culture media. The cells were then seeded into Corning 96-well solid black plates (VWR, Dublin, Ireland) at $2 \times 10^{5}$ cells ml ${ }^{-1}$ and treated with AgNP or Lipo-AgNP at $0.3 \mu \mathrm{g} \mathrm{ml}^{-1}$. ROS generation was then quantified by the fluorescence of the oxidized carboxy-DCFDA, by monitoring the dye emissions at 535 by $485 \mathrm{~nm}$ excitation on a Spectramax M3 multiplate reader, using multi-well scan at five different points per well.

\subsection{0 | Flow cytometry}

For flow cytometry analysis THP1 cells were seeded and cultured in T25 flasks at $2 \times 10^{5}$ cells ml $^{-1}$ and were subsequently treated with 
Lipo-AgNP and AgNP for 24 hours. After exposure, cells were harvested into $15 \mathrm{ml}$ tubes and were centrifuged at $300 \mathrm{~g}$ for 5 minutes at $22^{\circ} \mathrm{C}$ to form pellets. The pellets were resuspended in $2 \mathrm{ml}$ prewarmed $1 \times$ PBS and centrifuged as above and the process was repeated. Before staining the pellet was finally resuspended in $1 \mathrm{ml}$ binding buffer a $0.1 \% \mathrm{NaN}_{3}$ and $1 \%$ bovine serum albumin solution in $1 \times$ PBS.

For live-dead staining the cells were double stained by adding $5 \mu \mathrm{l}$ of $1 \mu \mathrm{M}$ calcein-AM stain and $10 \mu \mathrm{l}$ of $10 \mu \mathrm{g} \mathrm{ml}^{-1} \mathrm{Pl}$. The cells were then incubated in the dark at room temperature for 20 minutes and analysed with a BD Accuri C6 flow cytometer (BD, Oxford, UK).

For the cell cycle analysis, cells were harvested as above and rinsed in warm sterile PBS. The cells were then fixed with ice-cold $70 \%$ ethanol. After ethanol fixation, the cells were incubated at $4^{\circ} \mathrm{C}$ for up to 4 hours. Before any staining, the cells were washed twice in PBS and centrifuged at $800 \mathrm{~g}$ for 5 minutes and the cell pellet treated with $50 \mu \mathrm{l}$ of a $100 \mu \mathrm{g} \mathrm{ml}^{-1}$ ribonuclease A to ensure only DNA was stained. The cells were then stained with $400 \mu \mathrm{l}$ of $50 \mu \mathrm{g}$ $\mathrm{ml}^{-1} \mathrm{Pl}$ and incubated for 10 minutes before analysing using BD Accuri C6 flow cytometer.

Finally for Caspase3/7 analysis, as before the THP1 cells treated with AgNP and Lipo-AgNP were harvested and centrifuged at $300 \mathrm{~g}$ for 5 minutes to remove exposure solutions. As a positive control, THP1 cells were exposed to $1 \mu \mathrm{M}$ solution of doxorubicin, which is a known activator of the executioner caspases. The cells were washed in PBS once and then resuspended in binding buffer. The cells were then stained with $500 \mathrm{nM}$ CellEvent caspase 3/7 detection reagent and incubated at $37 \mathrm{C}$ for 30 minutes. The cells were then stained with $1 \mu \mathrm{M}$ SYTOX AAdvanced dead cell stain and incubated for 5 minutes before being analysed on a BD Accuri C6 flow cytometer.

\subsection{1 | Statistical analysis}

Statistical analysis was carried out using GraphPad Prism version 7. Data were analysed by two-way analysis of variance followed by Tukey's multiple comparison tests to detect significance in effects between exposure groups. Statistically significant differences in tests were indicated for $P<0.05$.

\section{3 | RESULTS}

\section{1 | Particle characterization}

A summary of the synthesized NPs characterization using DLS is shown in Table 1 for different dispersion environments. DLS analysis of AgNP showed a dramatic increase in mean particle size when dispersed in RPMI-1640 media when compared to dispersion in $d_{d H_{2}} \mathrm{O}$ from 21.24 to $79.15 \mathrm{~nm}$ respectively. This increase in size was accompanied by a change in colour of the AgNP when dispersed in RPMI1640 from the usual golden yellow colour to dark grey. In contrast, there was no significant change in the mean particle size of Lipo-AgNP when dispersed in RPMI-1640 compared to $\mathrm{ddH}_{2} \mathrm{O}$ and no colour change when dispersed in RPMI-1640 media. There was an observable increase in polydispersity index (PDI) of the AgNP (PDI = 0.23-0.566) and the Lipo-AgNP (PDI $=0.105-0.421$ ) when dispersed in water
TABLE 1 Size and zeta potential of AgNP, lyophilized and extruded Lipo-AgNP in $\mathrm{ddH}_{2} \mathrm{O}$ and RPMI-1640 media

\begin{tabular}{llcc} 
& & $\begin{array}{l}\text { In } \mathrm{ddH}_{2} \mathrm{O} \\
\text { Intensity PSD }\end{array}$ & $\begin{array}{l}\text { In media } \\
\text { Intensity PSD }\end{array}$ \\
\hline AgNP & DLS $(\mathrm{nm})$ & $21.14 \pm 9.48$ & $79.15 \pm 66.67$ \\
& Zeta $(\mathrm{mV})$ & -26.50 & -7.90 \\
& PDI & 0.230 & 0.566 \\
Extruded & DLS $(\mathrm{nm})$ & $140.1 \pm 47.49$ & $138.9 \pm 54.93$ \\
Lipo-AgNP & Zeta $(\mathrm{mV})$ & -31.9 & -0.61 \\
& PDI & 0.105 & 0.421
\end{tabular}

AgNP, silver nanoparticle; $\mathrm{ddH}_{2} \mathrm{O}$, distilled deionized water; DLS, dynamic light scattering; Lipo-AgNP, liposomal silver nanoparticle; PDI, polydispersity index; PSD, particle size distribution.

compared to dispersion in RPMI-1640 media. However, no sedimentation was observed for the AgNP when dispersed in RPMI-1640 likely due to the concentration used. There was a measurable drop in zeta potential values for AgNP (zeta $=-26.5$ to $-7.9 \mathrm{mV}$ ) and Lipo-AgNP (zeta $=-31.9$ to $-0.61 \mathrm{mV}$ ) when dispersed in $\mathrm{ddH}_{2} \mathrm{O}$ to RPMI-1640 media, indicating a less stable NP in RPMI-1640 media.

As shown in Figure 1(B), energy dispersive X-ray analysis confirmed the presence of elemental AgNP in the sample as the strong peak at $3 \mathrm{keV}$. The other peaks observed correspond to other elements due to sample preparation, the substrate (Si wafer) and carbon tab for conductive support. Result from XRD characterization of AgNP is shown in Figure S1(C). The XRD pattern shows four main peaks for AgNP at $2 \theta$ values of $38.30^{\circ}, 44.55^{\circ}, 64.60^{\circ}$ and $77.55^{\circ}$, which corresponds to (111), (200), (220) and (311) planes respectively for the facecentred cubic structure of metallic silver. This pattern is in agreement with that of the Joint Committee on Powder Diffraction Standards file no. 04-0783 confirming the crystalline structure of the synthesized AgNP (Luna, Barriga-Castro, Gómez-Treviño, Núñez, \& MendozaReséndez, 2016). The average size of synthesized AgNP was estimated by the Debye-Scherrer's equation (Equation 3 )

$$
D=\frac{0.9 \lambda}{\beta \operatorname{Cos} \theta}
$$

Where $D$ is the size of AgNP crystal in $n m, \lambda$ is the wavelength of the diffractometer, $\beta$ is the full width at half maximum intensity and $\theta$ is the Bragg angle. Based on the equation, the size of AgNP crystal was estimated to be $18.7 \mathrm{~nm}$, which was similar to that of the average size as determined by DLS measurement of $21.24 \mathrm{~nm}$.

SEM and STEM were used to evaluate the morphology of the NPs and to estimate the size distribution values of the NPs in dry state. The STEM analysis of AgNP showed all particles produced were spherical with an average size of $14.3 \pm 1.9 \mathrm{~nm}$, which is similar to that estimated by the XRD analysis (Figure S1A). SEM analysis of Lipo-AgNP showed spherical and uniformly extruded vesicles while the contrasting image of the STEM showed encapsulation of the AgNP in the liposome with an average size of $82.73 \pm 29.23 \mathrm{~nm}$ (Figure $2 \mathrm{~A}, \mathrm{~B}$ ), which displays size values less than the DLS values, which considering the hydrodynamic radius of the NPs was expected (Table 1). To confirm the encapsulation, DLS values of both AgNP before and after encapsulation were overlaid to determine if any unencapsulated AgNPs were present in the test sample (Figure 2C). As expected, there was no overlap in the size values showing successful encapsulation of AgNP. 

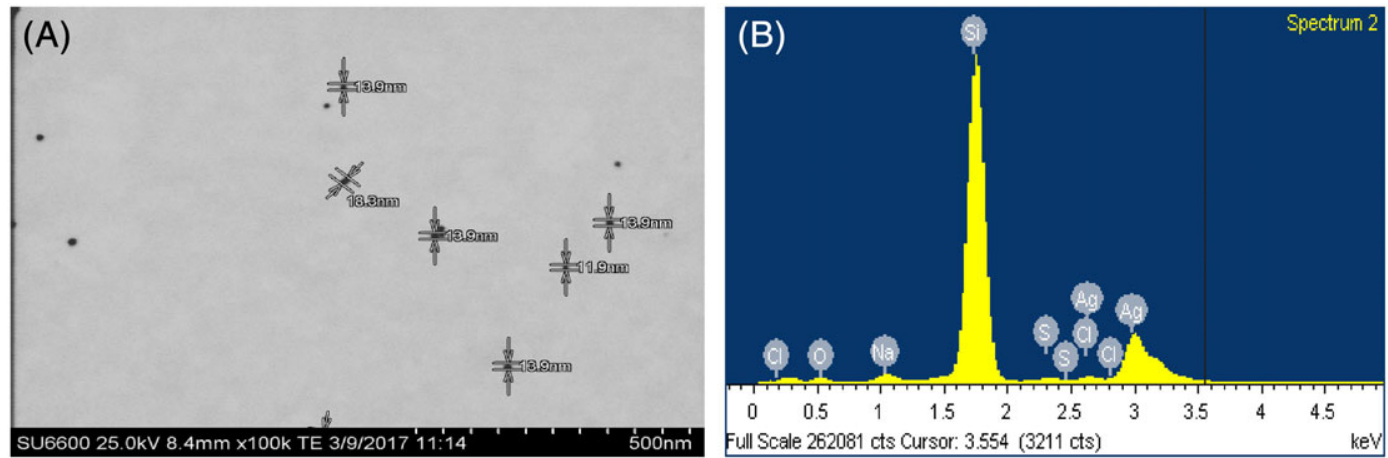

(C)

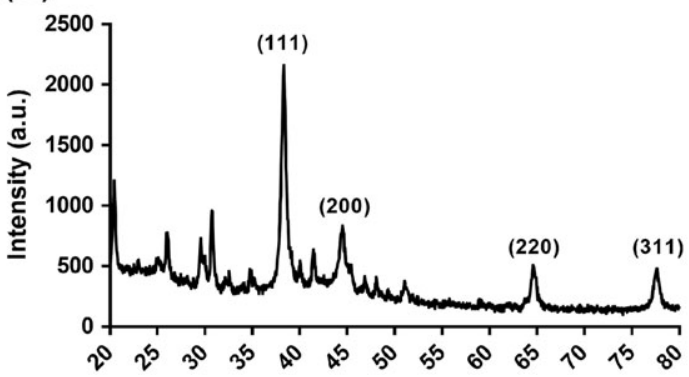

FIGURE 1 Silver nanoparticles characterisation by scanning transmission electron micrograph, energy dispersive X-ray and X-ray diffraction. Characterization of nanoparticles showing (a) scanning transmission electron micrograph, (b) energy dispersive X-ray analysis of silver nanoparticles on a silicon wafer and (C) X-ray diffraction pattern of silver nanoparticles synthesized by chemical reduction method
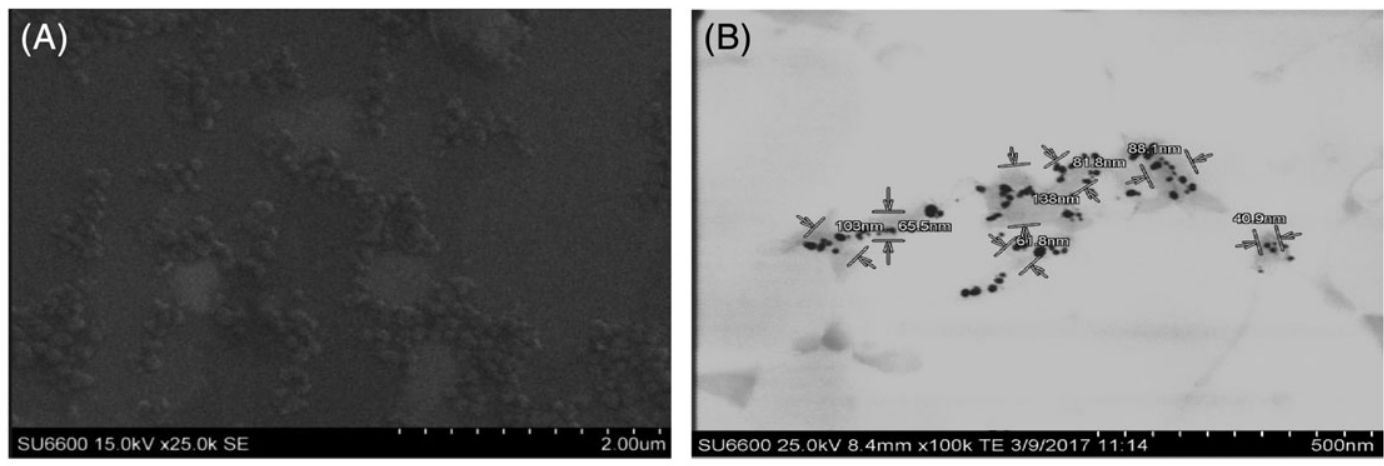

(C)

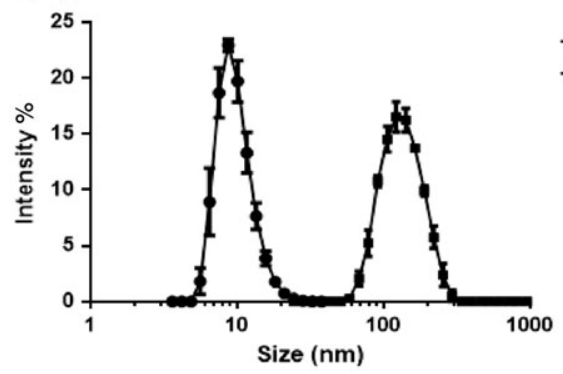

FIGURE 2 Lipo-AgNP characterization by scanning electron micrograph/scanning transmission electron micrograph and dynamic light scattering. Characterization of nanoparticles showing (a) scanning transmission electron micrograph, (b) scanning electron micrograph and (c) superposition of AgNP dynamic light scattering analysis before and after encapsulation in extruded liposome. AgNP, silver nanoparticle; Lipo-AgNP, liposomal silver nanoparticle

\subsection{Encapsulation efficiency}

Encapsulation efficiency of Lipo-AgNP was estimated based on Equation 2. A $10 \mu \mathrm{g} \mathrm{ml}^{-1} \mathrm{AgNP}$ solution (representing total AgNP added) was used to rehydrate the lipid film and the liposome was prepared as described above. The encapsulation efficiency of the different Lipo-AgNP preparations (Lipo-AgNP L1-L3) are shown in Table 2 was between $85 \%$ and $89 \%$ of the total AgNP added before encapsulation.

\section{3 | Cellular viability study}

The cell viability of THP1 cell line was evaluated by AB assay. The assay evaluates the ability of metabolically active cells to reduce 
TABLE 2 Encapsulation efficiency of Lipo-AgNP

\begin{tabular}{lccc} 
& $\begin{array}{l}\text { Lipo- } \\
\text { AgNP-L1 }\end{array}$ & $\begin{array}{l}\text { Lipo- } \\
\text { AgNP-L2 }\end{array}$ & $\begin{array}{l}\text { Lipo- } \\
\text { AgNP-L3 }\end{array}$ \\
\hline Total AgNP $\left(\mu \mathrm{g} \mathrm{ml}^{-1}\right)$ & 10.00 & 10.00 & 10.00 \\
$\begin{array}{c}\mathrm{AgNP} \text { in supernatant } \\
\left(\mu \mathrm{g} \mathrm{ml}^{-1}\right)\end{array}$ & 1.13 & 1.50 & 1.43 \\
\hline $\begin{array}{c}\text { Encapsulation efficiency } \\
\text { Ancon }\end{array}$ & $88.7 \%$ & $85.0 \%$ & $85.7 \%$
\end{tabular}

AgNP, silver nanoparticle; Lipo-AgNP, liposomal silver nanoparticle.

resazurin, a non-fluorescent blue dye to resorufin, a pink fluorescent product. Reduction of resazurin is done by both mitochondrial and cytoplasmic reducing agents such as $\mathrm{NADPH}, \mathrm{NADH}, \mathrm{FMNH}$ and $\mathrm{FADH}$, and as such the assay gives a broad indication of cellular viability (Rampersad, 2012). THP1 cells were exposed to varying concentrations of AgNP and Lipo-AgNP (0.3-5 $\left.\mathrm{g} \mathrm{ml}^{-1}\right)$ for 24 and 48 hours. To evaluate possible ionization of $\mathrm{AgNP}$ into $\mathrm{Ag}^{+}$, we exposed THP1 cells to same concentration of $\mathrm{Ag}^{+}$for 24 hours. At 24 hours, there was significant reduction in THP1 cell viability treated with $2.5 \mathrm{\mu g} \mathrm{ml}^{-1}$ of Lipo-AgNP and cells treated with $5 \mu \mathrm{g} \mathrm{ml}^{-1} \mathrm{AgNP}$ and Lipo-AgNP when compared with the unexposed control cells (Figure $3 A$ ). Interestingly, the cytotoxic effect of $\mathrm{Ag}^{+}$was threefold that of AgNP, showing a highly significant reduction in THP1 cell viability at concentrations $0.625-2.5 \mathrm{\mu g} \mathrm{ml}^{-1}$ and twofold reduction at $5 \mu \mathrm{g} \mathrm{ml} \mathrm{m}^{-1}$ after 24 hours. $\mathrm{Ag}^{+}$induced significant reduction in THP1 cell viability when compared with AgNP at concentrations $\geq 0.625 \mathrm{ug} \mathrm{ml}^{-1}$. The $\mathrm{IC}_{50}$ of AgNP, Lipo$\mathrm{AgNP}$ and $\mathrm{Ag}^{+}$at 24 hours was estimated to be 4.991, 3.045 and $0.3226 \mu \mathrm{g} \mathrm{ml}^{-1}$ respectively. At 48 hours, there was a significant reduction in cell viability for all exposure groups and concentration when compared to control. Interestingly, it induced a significant reduction in THP1 cell viability by $2.5 \mathrm{\mu g} \mathrm{ml}^{-1}$ of Lipo-AgNP compared to the $\mathrm{AgNP}$ at the same concentration (Figure 3B). Cell viability for $\mathrm{Ag}^{+}$was not carried out at 48 hours as $\leq 20 \%$ cell viability was already observed at 24 hours. To ensure the cytotoxic effect of Lipo-AgNP was due to the encapsulated AgNP and not the liposome, we exposed THP1 cells to empty liposome at the same concentrations with 1.25 and $2.5 \mu \mathrm{g}$ $\mathrm{ml}^{-1}$. THP1 cell viability after 24 hours' exposure showed no significant difference when compared with unexposed THP1 cells (Supporting information, Figure S1).
To verify the $A B$ findings, the levels of THP1 cell viability after exposure were monitored by flow cytometry. Flow cytometry is a single cell analysis method and because it gives a better indication of the exact viability levels in the exposures when compared to the $A B$ assay. THP1 cell death was evaluated by initially staining the cells with calcein-AM and PI 24 hours after being exposed to $0.625 \mathrm{\mu g} \mathrm{ml}^{-1}$ of AgNP and Lipo-AgNP. Compared to an unexposed control as with the previous viability measurements, $10 \%$ dimethyl sulfoxide medium solution was used as a positive control.

From the results obtained, there was no significant difference in the percentage of live cells between the control (98.35\%) and AgNPtreated cells (98.55\%) after 24 hours. However, we discovered a highly significant difference in the percentage of live cells treated with Lipo-AgNP (66.75\%) compared with AgNP (Figure 4). In both controlunexposed and AgNP-treated cells, only $0.5 \%$ cell death was observed after 24 hours. Contrarily, Lipo-AgNP treatment induced cell death in $32.5 \%$ of THP1 cells, a highly significant increase in cell death compared with both control-unexposed and AgNP-treated THP1 cells after 24 hours. This result suggests Lipo-AgNP is capable of inducing cell death at lower dose than that established by $A B$ assay.

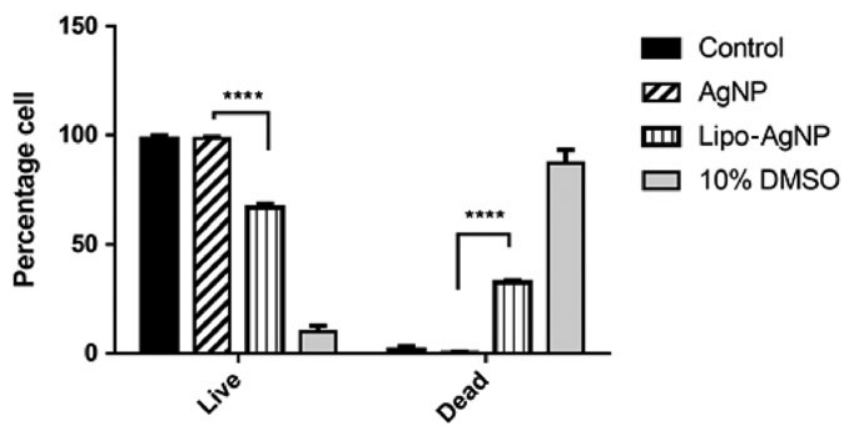

FIGURE 4 Lipo-AgNP induced THP1 cell death. Control THP1 cells, and cells treated with $0.625 \mathrm{mg} \mathrm{ml}^{-1}$ of AgNP and Lipo-AgNP and $10 \%$ DMSO were incubated for 24 hours and were washed in phosphate-buffered saline before staining with $10 \mathrm{\mu g} \mathrm{ml}^{-1}$ propidium iodide and $10 \mathrm{nM}$ calcein-AM. Data represent mean percentage \pm standard error of the mean $(n=3) .{ }^{* * * *} P<0.0001$. AgNP, silver nanoparticle; DMSO, dimethyl sulfoxide; Lipo-AgNP, liposomal silver nanoparticle
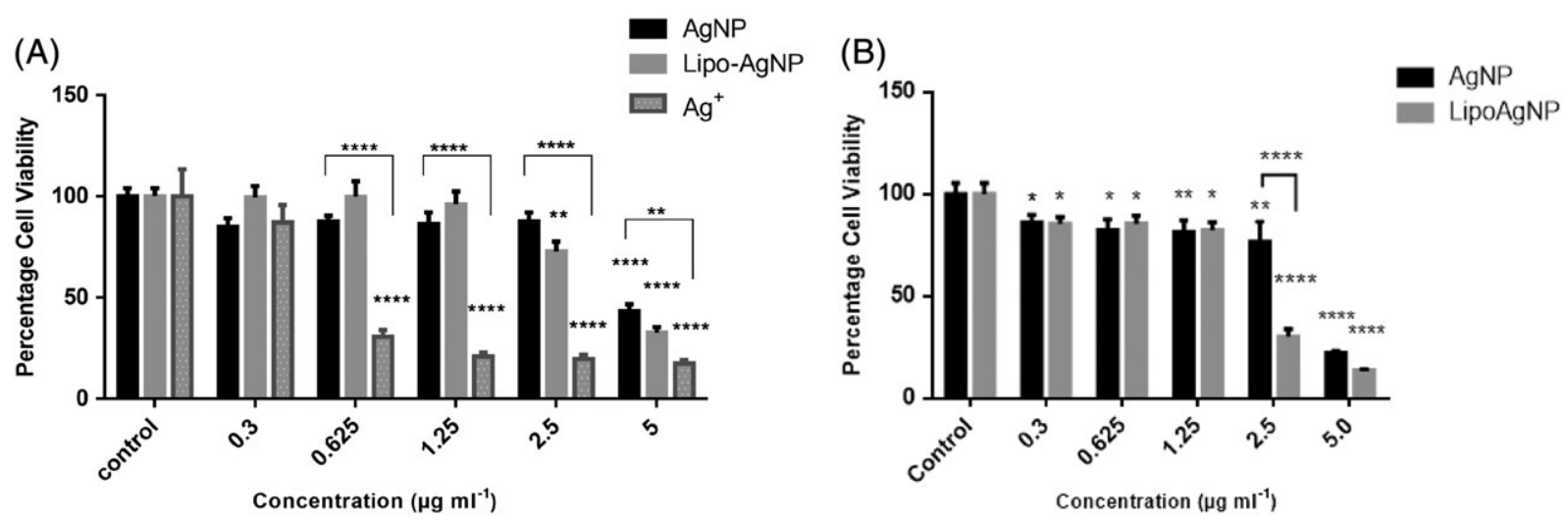

FIGURE 3 Cell viability of (a) AgNP, Lipo-AgNP and $\mathrm{Ag}^{+}$exposed cells at 24 hours and (b) AgNP and Lipo-AgNP at 48 hours as determined by the Alamar blue assay. Data are expressed as a percentage of three independent experiments \pm standard error of the mean of the four individual experiments and relative to a two-dimensional culture control. Statistically significant differences between the exposed viability responses and that of the control cultures are denoted by ${ }^{*} P<0.05,{ }^{* *} P<0.01,{ }^{* * *} P<0.0001$. AgNP, silver nanoparticle; Lipo-AgNP, liposomal silver nanoparticle 


\subsection{Cell cycle analysis}

THP1 cells were exposed to $0.625 \mu \mathrm{g} \mathrm{ml}{ }^{-1}$ of AgNP and LipoAgNP while unexposed cells were used as controls. Cell cycle analysis after 24 hours of exposure showed that exposure of THP1 cells to both AgNP and Lipo-AgNP did not affect the cell cycle progression from $G_{1}$ to $S$ phase and there was no significant difference between the exposed cells to control-unexposed cells. Exposure of THP1 cells to Lipo-AgNP resulted in $21.1 \%$ cells in the $G_{2} / M$ phase of the cell cycle. As expected, AgNP treatment did not show any effect on cells in the $G_{2} / M$ phase having $32.65 \%$ cells comparable to the $30.85 \%$ unexposed-control cells in $\mathrm{G}_{2} / \mathrm{M}$ phase. Interestingly, it was found that Lipo-AgNP treatment resulted in $8.4 \%$ cells in the sub- $\mathrm{G}_{1}$ phase compared with $0.65 \%$ and $0.8 \%$ cells for both unexposed-control and AgNP-treated cells respectively (Figure 5). This indicated that Lipo-AgNP at low doses caused DNA fragmentation, which was evident by the characteristic of sub- $G_{1}$ peak. The percentage of cells in the $G_{0} / G_{1}$ and $S$ phases remained the same in all groups, suggesting no apparent effect of treatment on cells in all exposure groups

\section{5 | Reactive oxygen species induction}

DNA fragmentation is one of the consequences of ROS generation before apoptosis. To determine if low-dose Lipo-AgNP was inducing the generation of ROS at sufficient levels to induce DNA damage, ROS levels were monitored in THP1 cells exposed to $0.3 \mu \mathrm{g} \mathrm{ml}^{-1}$ Lipo-AgNP at varying time points indicated in Figure 6 alongside an unexposed-control and uncapped AgNP to plot ROS generation as a function of time. From 30 minutes to 5 hours, there was an average of 1.5 -fold induction of ROS in cells exposed to $0.3 \mu \mathrm{g} \mathrm{ml}^{-1}$ of AgNP compared to control cell ROS. Cells exposed to the same concentration of Lipo-AgNP showed mild suppression of ROS induction up to 4 hours, which significantly increased to approximately threefold of control ROS at 24 hours. This indicates that ROS generation was not responsible for the observed cell death in THP1 cells exposed to $0.3 \mu \mathrm{g} \mathrm{ml}^{-1}$ of Lipo-AgNP.

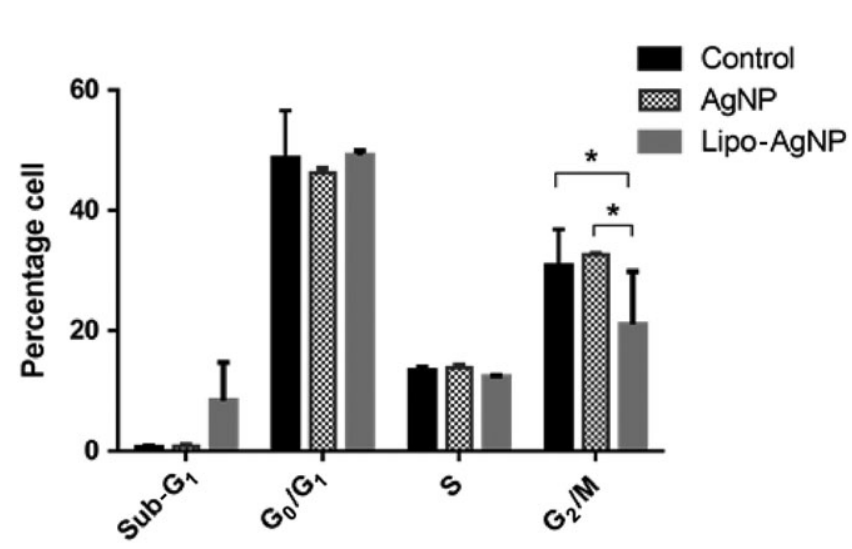

FIGURE 5 Lipo-AgNP treatment induced DNA fragmentation: THP1 cell lines were treated with $0.625 \mathrm{\mu g} \mathrm{ml}^{-1}$ of Lipo-AgNP and AgNP while unexposed cells and $10 \%$ dimethyl sulfoxide-treated cells were used as controls. Data represent mean percentage \pm SEM $(n=3),{ }^{*} P<$ 0.05. AgNP, silver nanoparticle; Lipo-AgNP, liposomal silver nanoparticle

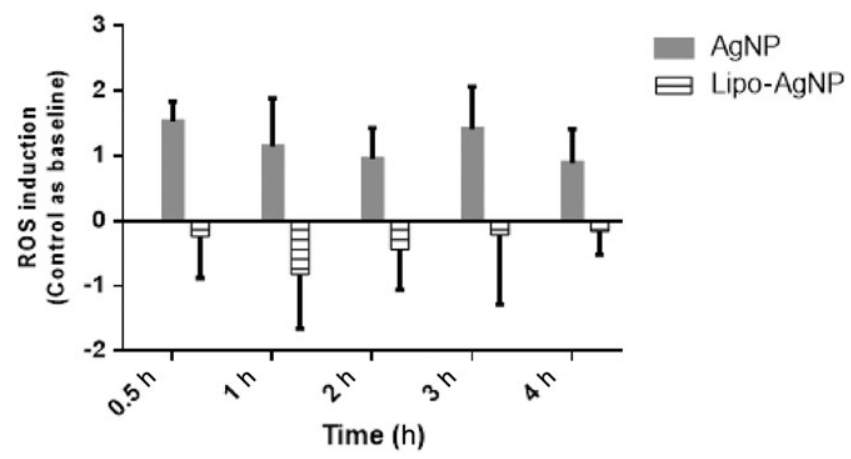

FIGURE 6 THP1 cell lines were loaded with $10 \mu \mathrm{M}$ 6-carboxy-2',7'dichlorofluorescein diacetate dye for 20 minutes. After which they were exposed to $0.3 \mu \mathrm{g} \mathrm{ml}^{-1} \mathrm{AgNP}$ and Lipo-AgNP for up to 4 hours. Control value was set as baseline for all time points and represented as mean \pm standard error of the mean $(n=3)$. AgNP, silver nanoparticle; Lipo-AgNP, liposomal silver nanoparticle; ROS, reactive oxygen species

\section{6 | Caspase activation}

ROS and DNA damage are known to be indicators of apoptosis and to verify this was the mechanism of action utilized by Lipo-AgNP, the CellEvent Caspase-3/7 Green Detection Reagent and SYTOX AADvanced Dead Cell Stain were employed. THP1 cells exposed to $0.625 \mu \mathrm{g} \mathrm{ml}^{-1}$ of AgNP and Lipo-AgNP were stained after 1, 4 and 24 hours of exposure. The result showed basal caspase activities at 1 and 4 hours in all exposure groups with an average of $2 \%$ of the total cell population exhibiting caspase activities. After 24 hours of exposure, the level of caspase activation remained the same for controlunexposed cells and AgNP-treated cells. Conversely, 33\% of total THP1 cells exposed to Lipo-AgNP were positive for caspase activation at 24 hours (Figure 7). This result suggested the cell death observed in Lipo-AgNP exposed cells was likely a consequence of caspase-3/7 activation.

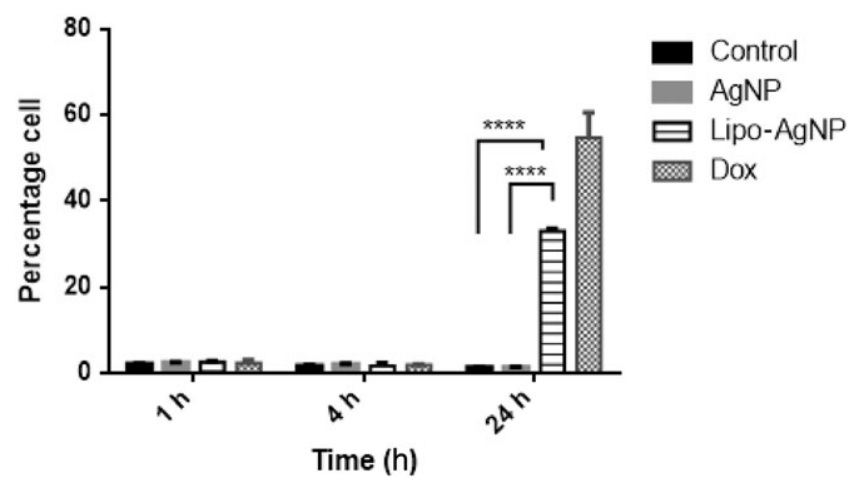

FIGURE 7 Lipo-AgNP activates caspase-dependent apoptosis in THP1 cells after 24 hours. THP1 cells that were unexposed, treated with $0.625 \mu \mathrm{g} \mathrm{ml}^{-1}$ of AgNP, $0.625 \mu \mathrm{g} \mathrm{ml}^{-1}$ of Lipo-AgNP and $1 \mu \mathrm{M}$ doxorubixin were stained with $500 \mathrm{nM}$ CellEvent $^{\mathrm{TM}}$ for 30 minutes and co-stained with $1 \mu \mathrm{M}$ Sytox AADvanced during the last 5 minutes. Data are represented as mean \pm standard error of the mean $(n=3)$, ${ }^{* * * *} P<0.0001$. AgNP, silver nanoparticle; Dox, doxorubixin; Lipo$\mathrm{AgNP}$, liposomal silver nanoparticle 
$8 \quad$ WILEY-AppliedToxicology

\section{I DISCUSSION}

Currently AgNPs are the main active ingredient in multiple nanoenabled commercial products worldwide, primarily due to their antimicrobial activities. Despite this, several studies have investigated and identified the cytotoxicity related hazards associated with AgNP (Connolly et al., 2015; Nowrouzi et al., 2010; Zhang, Wang, Chen, \& Chen, 2014). Interestingly, the increasing investigation of AgNP cytotoxicity has now moved beyond antibacterial applications and recent studies are investigating the potential of AgNPs as anticancer drugs. This shift is partially due to the evolution of multidrug-resistant cancer cells similar to that of antibiotic-resistant bacteria. Foldbjerg et al. (2012) noted that AgNP at an $\mathrm{EC}_{20}$ of $12.1 \mathrm{\mu g} \mathrm{ml}^{-1}$ showed potential anticancer properties such as induction of ROS, modulation of cell division and growth regulatory gene expressions such as cyclin B1 and histone $\mathrm{H} 1 \mathrm{~B}$ and the arrest of cells in the $\mathrm{G}_{2} / \mathrm{M}$ phase. Lin et al. (2014) showed that $10 \mu \mathrm{g} \mathrm{ml}^{-1}$ of AgNPs produced enhanced cytotoxicity in HeLa and B16 mouse melanoma cell lines that have undergone chemotherapeutic or genetically induced autophagy inhibition by preventing formation of anti-apoptotic autophagosomes normally induced by AgNP in these cell lines. Asharani et al. (2012) showed that $400 \mu \mathrm{g}$ $\mathrm{ml}^{-1}$ of AgNP induces activation of $\gamma \mathrm{H} 2 \mathrm{AX}$ foci, suppresses expression of key cell cycle proteins such as p21, p53 and cyclin B, and induces the expression of DNA damage response genes RPA1 and FEN1. Several other studies evaluating the antibacterial properties and mechanism of action of AgNP have shown the minimum inhibitory concentration of AgNP from $10 \mathrm{\mu g} \mathrm{ml}^{-1}$ to as high as $180 \mu \mathrm{g} \mathrm{ml}^{-1}$ for different bacteria strains (Amato et al., 2011; Bao et al., 2015; Guzman, Dille, \& Godet, 2012; Hsueh et al., 2015; Maiti, Krishnan, Barman, Ghosh, \& Laha, 2014). None the less, all of these studies have investigated AgNP activities at high concentrations, which are likely to be detrimental to human health, thus limiting the potential therapeutic applications. Hence, this necessitates development of delivery systems capable of delivering AgNPs intracellularly at a lower concentration to achieve the desired pharmacological response.

In this study, an in-house synthesized AgNP was encapsulated to improve the in vitro delivery of the AgNP to enhance their in vitro effects and simultaneously reduce the dose required. NPs are found in bodily tissues and fluid after entering the body through different routes such as oral, intravenous, transdermal or inhalation (Yildirimer, Thanh, Loizidou, \& Seifalian, 2011). The use of THP1 in the study was to mimic such presence in the blood system because of relocation in a diseased condition and as an enhanced delivery mechanism for cancer. There are multiple reports on the effect of NP size on drug delivery and cellular internalization. NPs of larger sizes ( $<500 \mathrm{~nm})$ are, in addition to hepatic uptake, more prone to clearance by the reticuloendothelial system resulting in reduced bioavailability and pharmacological potential (Alexis, Pridgen, Molnar, \& Farokhzad, 2008; Omar Zaki, Ibrahim, \& Katas, 2015). Both the DLS and SEM/STEM characterization showed the sizes of the AgNP and Lipo-AgNP to be below 30 and $200 \mathrm{~nm}$ respectively. In general, DLS values were slightly higher than that of the SEM values and this was as expected as the DLS is an intensity measurement that tracks the hydrodynamic radius of the solvated NP while SEM/STEM imaging is a physical snapshot of the dry particles with no influence from surrounding solvent. As such, the hydrodynamic radius, which includes the aqueous layer, tends to be slightly larger than dry particle radius. The XRD pattern analysis using the Debye-Scherrer equation estimated a size of $18.7 \mathrm{~nm}$ and peak pattern that is characteristic of a face-centred cubic crystalline structure. This finding is in agreement to those of other studies further confirming the sample as metallic silver (Anandalakshmi, Venugobal, \& Ramasamy, 2016; Bindhu \& Umadevi, 2015). However, there are two peaks around $26^{\circ}$ and $30.7^{\circ}$, which are not characteristic of silver. These peaks may be generated by the $\mathrm{NaBH}_{4}$ reducing agent used in chemical reduction of $\mathrm{AgNO}_{3}$ and it is similar to those reported in other studies for $\mathrm{NaBH}_{4}$ (Agnihotri, Mukherji, \& Mukherji, 2014; Su, Lu, Wang, \& Huang, 2012).

Several studies have noted particle size changes of AgNP in cell culture environments, as such the size distributions of AgNP and Lipo-AgNP in culture media were monitored and compared to those in water. An AgNP size increase from 21.14 to $79.15 \mathrm{~nm}$ was observed in media compared to when dispersed in water. This size increase was presumed to be an indication of NP agglomeration in the solution. In contrast, this was not the same for Lipo-AgNP where there was a slight reduction in recorded sizes (140.1 nm in water and $138.9 \mathrm{~nm}$ in media). Previous studies have reported an increase in AgNP size in culture media and this increase in size has been proposed to be due to an association of AgNP with proteins (Hansen \& Thunemann, 2015; Mukherjee, O'Claonadh, Casey, \& Chambers, 2012; Murphy, Sheehy, Casey, \& Chambers, 2015; Shannahan et al., 2013). The interaction of AgNP with protein in culture media was most likely prevented by Lipo-AgNP due to the presence of the protective lipid layer, preventing the encapsulated AgNP from directly interacting with biomolecules in the milieu of the culture media. Additionally, there was an increase in PDI values for AgNP in both water and RPMI-1640, the difference in these PDI values for AgNP was higher than that of Lipo-AgNP. PDI value increases indicate an increased non-uniformity of the NPs when they were dispersed into the culture media. These findings suggest encapsulation and formation of the Lipo-AgNP suppresses the changes in morphology of AgNP in culture media and ultimately improves their stability in comparison to standard AgNP.

After dispersion, cellular viability levels of THP1 cells exposed to varying concentration of AgNP and Lipo-AgNP (0.3-5 $\mu \mathrm{g} \mathrm{ml}^{-1}$ ) for 24 and 48 hours were monitored with the $A B$ assay. The results showed a dose-dependent reduction in cell viability with a greater level of cytotoxicity observed for the Lipo-AgNP-treated cells. A significant THP1 cell viability reduction was observed at $2.5 \mu \mathrm{g} \mathrm{ml}^{-1}$ Lipo-AgNP treatment $(P<0.05)$ and interestingly not for AgNP of the same concentration after 24 hours. In contrast, there was a significant reduction in cell viability of THP1 cells treated with $2.5 \mathrm{\mu g} \mathrm{ml}^{-1}$ Lipo-AgNP compared to AgNP of the same concentration at 48 hours $(P<0.0001)$, suggesting Lipo-AgNP were more cytotoxic than AgNP. AgNP only induced significant reduction in cell viability at $5 \mu \mathrm{g} \mathrm{ml}^{-1}$ and $\geq 2.5 \mu \mathrm{g}$ $\mathrm{ml}^{-1}$ at 24 and 48 hours respectively when compared to control. This finding is in agreement with those of other studies that investigated dose-dependent cytotoxicity of AgNP on different human cell lines. Jiang et al. (2013) reported significant reduction of Chinese hamster ovary $\mathrm{k} 1$ cell viability at concentrations $\geq 5 \mathrm{\mu g} \mathrm{ml}^{-1}$ at 24 hours using MTT assay. Juarez-Moreno et al. (2016) in their study reported similar AgNP $I C_{50}$ to that of this study in addition to significant reduction in 
cell viability at AgNP concentrations $\geq 1.25 \mu \mathrm{g} \mathrm{ml}^{-1}$ for eight different human cancer cell lines where viability was monitored with the MTT assay. Variations in the cytotoxicity of AgNP in these cell lines could be attributed to the difference in sensitivity of the cell lines to the NP but also differences in assays employed to monitor viability. Interestingly, Murphy, Casey, Byrne, Chambers, and Howe (2016) who used THP1 cells reported dose-dependent cytotoxicity of AgNP (50-70 nm size) with significant difference from $\geq 1.9 \mu \mathrm{g} \mathrm{ml}^{-1}$. This contrasted with our findings and could be due to polyvinyl pyrrolidine-coated AgNP used in the study, which may have its own inherent toxicity. Of course, it may be because of a difference in particle sizes, which have been previously shown to mediate cytotoxicity irrespective of capping agent used (Gliga, Skoglund, Wallinder, Fadeel, \& Karlsson, 2014).

$\mathrm{AgNP}$ ionization into $\mathrm{Ag}^{+}$has been widely proposed as its mechanism of action in inducing cytotoxicity (Hsueh et al., 2015; Lansdown, 2010). As such, we investigated the cytotoxicity of $\mathrm{Ag}^{+}$on THP1 cells and our findings indicate that $\mathrm{Ag}^{+}$at concentrations between 0.625 and $2.5 \mu \mathrm{g} \mathrm{ml}^{-1}$ reduced THP1 cell viability by more than threefold while twofold reduction in cell viability was observed for THP1 exposed to $5 \mu \mathrm{g} \mathrm{ml}^{-1} \mathrm{Ag}^{+}$when compared with AgNP at the same concentrations. This finding is in agreement with that of Foldbjerg et al. (2009) who used flow cytometric analysis to determine viability of THP1 cells after exposure to AgNP and $\mathrm{Ag}^{+}$. Their findings showed at least a twofold reduction in THP1 cell viability after exposure to $\geq 0.625 \mu \mathrm{g} \mathrm{ml}^{-1} \mathrm{Ag}^{+}$. There was a similar concentration-dependent cytotoxicity profile for both $\mathrm{AgNP}$ and $\mathrm{Ag}^{+}$although $\mathrm{Ag}^{+}$had higher toxicity. Taken together, ionization of $\mathrm{AgNP}$ into $\mathrm{Ag}^{+}$is likely responsible for the cytotoxic effect of AgNP. The lower cytotoxic effect of AgNP may be because of its slow ionization rate as it has been reported that the AgNP ionization rate correlates with its concentration (Maurer-Jones, Mousavi, Chen, Buhlmann, \& Haynes, 2013). This is also supported by the reduction in $\mathrm{Ag}^{+}$cytotoxic effect to twofold relative to that of AgNP at $5 \mu \mathrm{g} \mathrm{ml}^{-1}$. This may be consequent upon increased ionization of $\mathrm{AgNP}$ with increased concentration. In addition, the steady reduction in THP1 cell viability after 48 hours of exposure to $0.625-2.5 \mu \mathrm{g} \mathrm{ml}^{-1}$ of AgNP also supports this notion.

To verify the results of the $A B$ assay, flow cytometry, which is a more sensitive technique, was employed to evaluate cell viability after exposure to THP1 cells with AgNP and Lipo-AgNP. Calcein-AM and PI staining of THP1 cells after 24 hours of treatment with $0.625 \mathrm{\mu g} \mathrm{ml}^{-1}$ Lipo-AgNP showed induction of a significant amount of death in the cells $(P<0.0001)$. Conversely, AgNP treatment showed a comparable outcome to control-unexposed cells with little or no cell death observed, verifying the $A B$ assay results that the Lipo-AgNP exhibited a higher level of cytotoxicity than AgNP alone.

Several studies have shown that AgNP can initiate cell cycle arrest at different phases of the cell cycle including the $G_{0} / G_{1}, S$ and $G_{2} / M$ phases (Asharani et al., 2012; De Matteis et al., 2015; Eom \& Choi, 2010). As such, the effect of low-dose Lipo-AgNP on the THP1 cell cycle was monitored. Our findings showed normal progression of THP1 cells from the $G_{1}$ to the S-phase for all exposure and control groups. On the contrary, Lipo-AgNP exposure resulted in a significant reduction in $G_{2} / M$ cell population compared with the control and AgNP-treated cells $(P<0.05)$. In the S-phase, cells that have successfully passed through the $G_{1} / S$ checkpoint replicate their DNA in preparation for progression into the $G_{2} / M$ phase where they divide during mitosis (Takeda \& Dutta, 2005). DNA damage in the $\mathrm{S}$ phase results in activation of ataxia-telangiectasia-mutated and ataxia-telangiectasia-related kinases, which in turn activate CHK2, $\gamma \mathrm{H} 2 \mathrm{AX}$ and the BRCA genes to slow down replication through abrogation of origin firing and signal DNA damage for repair. Increased DNA damage, however, results in induction of apoptosis by ataxia-telangiectasia-mutated, ataxia-telangiectasia-related and CHK2 activation of p53 (Norbury \& Zhivotovsky, 2004; Willis \& Rhind, 2009). A population in the sub- $G_{1}$ upon Lipo-AgNP exposure was noted and such populations are known to be cells with fragmented DNA that are undergoing or have undergone apoptosis. A genomic DNA fragmenting effect of AgNP has indeed been previously demonstrated by Awasthi et al. (2013) and may be occurring in this study after exposure to Lipo-AgNP. The proportion of cells observed in the sub- $\mathrm{G}_{1}$ recorded because of Lipo-AgNP exposure matches the reduction in the $G_{2} / M$ phase. This may indicate the cells were forced out of the cell cycle due to the increased DNA damage because of Lipo-AgNP exposure and died via apoptotic mechanisms.

The cell induces apoptosis for many reasons, one of which is to maintain genome integrity by killing cells with a high amount of DNA damage. ROS induction is often used to activate the signalling cascade that results in apoptotic induction in such cells. ROS are known to disrupt the mitochondrial membrane that results in the release of cytochrome $c$. Release of cytochrome $c$ activates the proapoptotic Bcl2 proteins Bax and Bak, which in turn activate executioner caspases 3 and 7 (Quast, Berger, \& Eberle, 2013). There are reports in the literature indicating that AgNPs cause apoptosis by inducing increased generation of ROS. Indeed Kang et al. (2012) and Foldbjerg, Dang, and Autrup (2011) reported a dose- and time-dependent ROS-induced apoptosis in dendritic cell line (DC2.4) and A549 lung cell lines respectively because of AgNP exposure. Awasthi et al. (2013) also reported a dose-dependent ROS generation and induction of apoptosis in Chinese hamster ovary cell lines. To monitor if this was occurring here because of the Lipo-AgNP exposure, ROS generation was monitored in THP1 cell lines. The cells were treated with a low concentration of AgNP and Lipo-AgNP $\left(0.3 \mu \mathrm{g} \mathrm{ml}^{-1}\right)$ for up to 4 hours to evaluate the onset of ROS generation. It was noted that AgNP exposure did induce ROS, but non-significant levels of ROS with respect to the controls, most likely because the concentrations considered were not cytotoxic to the cells. In contrast to the previous studies, this study showed that Lipo-AgNP did not induce ROS generation to cause THP1 cell death. In fact, there was an observable suppression of ROS induction. The variation in these studies can likely be due to several factors, which include but are not limited to differences in cell lines, size and surface characteristics of the AgNP used.

The literature indicates cell death because of AgNP exposure is typically due to ROS generation with subsequent DNA damage to the cells followed by apoptosis. However, findings of this study suggested ROS was not involved in the induction of observed cell death when studying the Lipo-AgNP. One of the downstream factors activated by $\mathrm{p} 53$ signalling after sensing DNA damage is caspase 3 . Different studies have shown that activation of p53 in response to DNA damage results in p53 transcriptional upregulation of Puma and Noxa, 
inhibitors of $\mathrm{Bcl}-2, \mathrm{Bcl}-\mathrm{xl}$ and $\mathrm{Mcl}-1$. Inhibition of these $\mathrm{Bcl}$ proteins result in Bax and Bak activation, which ultimately result in cytochrome $c$ release and activation of the executioner caspases (Ashkenazi, 2008). To explore the possibility of ROS-independent induction of apoptosis, activation of caspases $3 / 7$ in THP1 cells treated with the same lowdose AgNP and Lipo-AgNP at 1, 4 and 24 hours to monitor onset of activation was investigated. For all cell groups, there was no significant activation of caspases $3 / 7$ at 1 and 4 hours. On the other hand, there was a significant induction of caspases $3 / 7$ in THP1 cells treated with $0.625 \mu \mathrm{g} \mathrm{ml}^{-1}$ of Lipo-AgNP after 24 hours $(P<0.0001)$.

Previous studies have linked the AgNP mechanism of action to increased generation of ROS, which causes depolarization of the mitochondrial membrane potential and subsequent rupture of the membrane for release of cytochrome $c$ (Foldbjerg et al., 2011; Jiang et al., 2013; Kang et al., 2012). This has been proposed to be achieved by the intracellular oxidation of $\mathrm{AgNP}$ to $\mathrm{Ag}^{+}$by the acidic environment in the lysosome (De Matteis et al., 2015). Endocytosis of AgNP is believed to result in the compartmentalization of the NP in an endosome, which is metabolized in the endolysosomal pathway thus leading to its oxidation and generation of ROS. Our findings have interestingly opened an alternative pathway to ROS-dependent apoptosis induction by AgNP. In this study, it was shown that encapsulation of AgNP in liposomes was able to achieve greater cytotoxicity at low dose compared to what was achievable at high doses, in a ROS-independent way. This may be attributed to the improved delivery of AgNP into the cells via the liposome as the lipid layer can easily traverse the lipid bilayer of the cell membrane due to the hydrophobic interactions when compared to unencapsulated AgNP. Lipo-AgNP may also suppress the ionization of AgNP as part of its mechanism to prevent ionizationdependent generation of ROS. Conventional drugs encapsulated in liposome are known to have an increased bioavailability, enhanced permeability and retention effect (Maeda, 2012). These characteristics enhance the pharmacokinetics of Lipo-AgNP in the cells resulting in efficient delivery of AgNPs into the cell. Lysosomal breakdown of the lipid layer will result in overwhelming delivery of AgNP into the cytoplasm and subsequently in the nucleus allowing interaction between AgNP and the DNA causing DNA damage and halted replication (Li, Zhao, Hammer, Du, \& Chen, 2013; Pramanik, Chatterjee, Saha, Devi, \& Suresh Kumar, 2016). The DNA damage could be responsible for the activation of executioner caspases consequent upon activation of p53. Taken together, this suggests a 'Trojan Horse' effect mechanism for Lipo-AgNP due to the sudden leakage of AgNP into the cytoplasm and subsequently the nucleus after degradation of the liposome. This stealth mechanism none the less, is in contrast with the type previously described for AgNP in other studies where AgNP is phagocytosed, ionized and released to enhance the generation of ROS, which in turn stimulates inflammatory responses that can mediate cell death (Park, Yi, Kim, Choi, \& Park, 2010).

The cytotoxicity induced by Lipo-AgNP independent of ROS generation offers some advantages if properly harnessed. ROS is known to induce cellular senescence in neighbouring cells and this is accompanied by upregulation of stress and inflammatory genes through secretion of proinflammatory molecules such as nuclear factor kappa B (Correia-Melo, Hewitt, \& Passos, 2014). In addition, ROS-mediated necrosis of cells could result in the release of cytoplasmic wastes that can cause exaggerated and unscheduled inflammatory responses, which may promote tumour development (Vakkila \& Lotze, 2004). As such, these secondary effects can be prevented by coating the AgNP surface in a protective layer as demonstrated in this study.

\section{5 | CONCLUSION}

In this work, the encapsulation of AgNP in a liposome has been demonstrated to enhance AgNP cytotoxicity at low concentrations through increased DNA damage with suppression of ROS. This contrast with several other studies that have shown that AgNP cytotoxic effect can only be achieved through the generation of ROS. It is postulated that the encapsulation of AgNP in liposomes could eliminate the negative side effects of ROS making it possible to achieve a greater level of cytotoxicity that would otherwise only be possible at high concentrations. As such, Lipo-AgNP could reduce the concentration of AgNP required thereby increasing any potential biological activity with reduced associated side effects typically caused from high-dose exposures.

\section{ACKNOWLEDGMENTS}

This research work and Azeez Yusuf was supported by the Dublin Institute of Technology's Fiosraigh Dean of Graduate's Research Fellowship. Alan Casey acknowledges the support of the Science Foundation Ireland Principal Investigator Award 11/PI/1108.

\section{CONFLICT OF INTEREST}

The authors did not report any conflict of interest.

\section{ORCID}

A. Yusuf (D) http://orcid.org/0000-0001-5241-6620

\section{REFERENCES}

Agnihotri, S., Mukherji, S., \& Mukherji, S. (2014). Size-controlled silver nanoparticles synthesized over the range 5-100 nm using the same protocol and their antibacterial efficacy. RSC Advances, 4, 3974-3983.

Alexis, F., Pridgen, E., Molnar, L. K., \& Farokhzad, O. C. (2008). Factors affecting the clearance and biodistribution of polymeric nanoparticles. Molecular Pharmaceutics, 5, 505-515.

Amato, E., Diaz-Fernandez, Y. A., Taglietti, A., Pallavicini, P., Pasotti, L., Cucca, L., ... Necchi, V. (2011). Synthesis, characterization and antibacterial activity against gram positive and gram negative bacteria of biomimetically coated silver nanoparticles. Langmuir, 27, 9165-9173.

Anandalakshmi, K., Venugobal, J., \& Ramasamy, V. (2016). Characterization of silver nanoparticles by green synthesis method using Pedalium murex leaf extract and their antibacterial activity. Applied Nanoscience, 6, 399-408.

Asharani, P., Sethu, S., Lim, H. K., Balaji, G., Valiyaveettil, S., \& Hande, M. P. (2012). Differential regulation of intracellular factors mediating cell cycle, DNA repair and inflammation following exposure to silver nanoparticles in human cells. Genome Integrity, 3, 2.

Ashkenazi, A. (2008). Directing cancer cells to self-destruct with pro-apoptotic receptor agonists. Nature Reviews. Drug Discovery, 7, 1001-1012.

Awasthi, K. K., Awasthi, A., Kumar, N., Roy, P., Awasthi, K., \& John, P. (2013). Silver nanoparticle induced cytotoxicity, oxidative stress, and DNA damage in CHO cells. Journal of Nanoparticle Research, 15, 1898. 
Bao, H., Yu, X., Xu, C., Li, X., Li, Z., Wei, D., \& Liu, Y. (2015). New toxicity mechanism of silver nanoparticles: Promoting apoptosis and inhibiting proliferation. PLoS One, 10, e0122535.

Benn, T., Cavanagh, B., Hristovski, K., Posner, J. D., \& Westerhoff, P. (2010). The release of nanosilver from consumer products used in the home. Journal of Environmental Quality, 39, 1875-1882.

Benn, T. M., \& Westerhoff, P. (2008). Nanoparticle silver released into water from commercially available sock fabrics. Environmental Science \& Technology, 42, 4133-4139.

Bindhu, M. R., \& Umadevi, M. (2015). Antibacterial and catalytic activities of green synthesized silver nanoparticles. Spectrochimica Acta. Part A, Molecular and Biomolecular Spectroscopy, 135, 373-378.

Blaske, F., Reifschneider, O., Gosheger, G., Wehe, C. A., Sperling, M., Karst, U., ... Höll, S. (2013). Elemental bioimaging of nanosilver-coated prostheses using $\mathrm{X}$-ray fluorescence spectroscopy and laser ablationinductively coupled plasma-mass spectrometry. Analytical Chemistry, 86, 615-620.

Bozzuto, G., \& Molinari, A. (2015). Liposomes as nanomedical devices. International Journal of Nanomedicine, 10, 975.

Briuglia, M. L., Rotella, C., McFarlane, A., \& Lamprou, D. A. (2015). Influence of cholesterol on liposome stability and on in vitro drug release. Drug Delivery and Translational Research, 5, 231-242.

Brown, S., \& Khan, D. R. (2012). The treatment of breast cancer using liposome technology. Journal of Drug Delivery, 2012, 212965.

Camacho, K. M., Menegatti, S., Vogus, D. R., Pusuluri, A., Fuchs, Z., Jarvis, M., ... Mitragotri, S. (2016). DAFODIL: A novel liposome-encapsulated synergistic combination of doxorubicin and $5 \mathrm{FU}$ for low dose chemotherapy. Journal of Controlled Release, 229, 154-162.

Connolly, M., Fernandez-Cruz, M. L., Quesada-Garcia, A., Alte, L., Segner, H., \& Navas, J. M. (2015). Comparative cytotoxicity study of silver nanoparticles (AgNPs) in a variety of rainbow trout cell lines (RTL-W1, RTH-149, RTG-2) and primary hepatocytes. International Journal of Environmental Research and Public Health, 12, 5386-5405.

Correa, J. M., Mori, M., Sanches, H. L., Da Cruz, A. D., Poiate, E. Jr., \& Poiate, I. A. (2015). Silver nanoparticles in dental biomaterials. International Journal of Biomaterials, 2015, 485275.

Correia-Melo, C., Hewitt, G., \& Passos, J. F. (2014). Telomeres, oxidative stress and inflammatory factors: Partners in cellular senescence? Longev Healthspan, 3, 1.

De Matteis, V., Malvindi, M. A., Galeone, A., Brunetti, V., De Luca, E., Kote, S., ... Pompa, P. P. (2015). Negligible particle-specific toxicity mechanism of silver nanoparticles: The role of $\mathrm{Ag}+$ ion release in the cytosol. Nanomedicine, 11, 731-739.

Eom, H.-J., \& Choi, J. (2010). p38 MAPK activation, DNA damage, cell cycle arrest and apoptosis as mechanisms of toxicity of silver nanoparticles in Jurkat T cells. Environmental Science \& Technology, 44, 8337-8342.

Feng, Q. L., Wu, J., Chen, G. Q., Cui, F. Z., Kim, T. N., \& Kim, J. O. (2000). A mechanistic study of the antibacterial effect of silver ions on Escherichia Coli and Staphylococcus Aureus. Journal of Biomedical Materials Research, 52, 662-668.

Foldbjerg, R., Dang, D. A., \& Autrup, H. (2011). Cytotoxicity and genotoxicity of silver nanoparticles in the human lung cancer cell line, A549. Archives of Toxicology, 85, 743-750.

Foldbjerg, R., Irving, E. S., Hayashi, Y., Sutherland, D. S., Thorsen, K., Autrup, H., \& Beer, C. (2012). Global gene expression profiling of human lung epithelial cells after exposure to nanosilver. Toxicological Sciences, 130, 145-157.

Foldbjerg, R., Olesen, P., Hougaard, M., Dang, D. A., Hoffmann, H. J., \& Autrup, H. (2009). PVP-coated silver nanoparticles and silver ions induce reactive oxygen species, apoptosis and necrosis in THP-1 monocytes. Toxicology Letters, 190, 156-162.

Gliga, A. R., Skoglund, S., Wallinder, I. O., Fadeel, B., \& Karlsson, H. L. (2014). Size-dependent cytotoxicity of silver nanoparticles in human lung cells: The role of cellular uptake, agglomeration and $\mathrm{Ag}$ release. Particle and Fibre Toxicology, 11, 11.
Grigor'eva, A., Saranina, I., Tikunova, N., Safonov, A., Timoshenko, N., Rebrov, A., \& Ryabchikova, E. (2013). Fine mechanisms of the interaction of silver nanoparticles with the cells of salmonella typhimurium and Staphylococcus Aureus. Biometals, 26, 479-488.

Guzman, M., Dille, J., \& Godet, S. (2012). Synthesis and antibacterial activity of silver nanoparticles against gram-positive and gram-negative bacteria. Nanomedicine, 8, 37-45.

Hansen, U., \& Thunemann, A. F. (2015). Characterization of silver nanoparticles in cell culture medium containing fetal bovine serum. Langmuir, $31,6842-6852$.

Hsueh, Y. H., Lin, K. S., Ke, W. J., Hsieh, C. T., Chiang, C. L., Tzou, D. Y., \& Liu, S. T. (2015). The antimicrobial properties of silver nanoparticles in Bacillus Subtilis are mediated by released $\mathrm{Ag}^{+}$ions. PLoS One, 10, e0144306.

Jiang, X., Foldbjerg, R., Miclaus, T., Wang, L., Singh, R., Hayashi, Y., ... Beer, C. (2013). Multi-platform genotoxicity analysis of silver nanoparticles in the model cell line CHO-K1. Toxicology Letters, 222, 55-63.

Juarez-Moreno, K., Gonzalez, E. B., Girón-Vazquez, N., Chávez-Santoscoy, R. A., Mota-Morales, J. D., Perez-Mozqueda, L. L., ... Bogdanchikova, N. (2016). Comparison of cytotoxicity and genotoxicity effects of silver nanoparticles on human cervix and breast cancer cell lines. Human \& Experimental Toxicology, 36, 931-948.

Kang, K.-A., Jung, H.-Y., \& Lim, J.-S. (2012). Cell death by polyvinylpyrrolidine-coated silver nanoparticles is mediated by ROSdependent signaling. Biomolecules \& Therapeutics, 20, 399-405.

Knetsch, M. L., \& Koole, L. H. (2011). New strategies in the development of antimicrobial coatings: The example of increasing usage of silver and silver nanoparticles. Polymer, 3, 340-366.

Lansdown, A. B. (2010). A pharmacological and toxicological profile of silver as an antimicrobial agent in medical devices. Advances in Pharmacological Sciences, 2010, 910686.

Li, K., Zhao, X., Hammer, B. K., Du, S., \& Chen, Y. (2013). Nanoparticles inhibit DNA replication by binding to DNA: Modeling and experimental validation. ACS Nano, 7, 9664-9674.

Lin, J., Huang, Z., Wu, H., Zhou, W., Jin, P., Wei, P., ... Wen, L. (2014). Inhibition of autophagy enhances the anticancer activity of silver nanoparticles. Autophagy, 10, 2006-2020.

Luna, C., Barriga-Castro, E. D., Gómez-Treviño, A., Núñez, N. O., \& Mendoza-Reséndez, R. (2016). Microstructural, spectroscopic, and antibacterial properties of silver-based hybrid nanostructures biosynthesized using extracts of coriander leaves and seeds. International Journal of Nanomedicine, 11, 4787-4798.

Maeda, H. (2012). Vascular permeability in cancer and infection as related to macromolecular drug delivery, with emphasis on the EPR effect for tumor-selective drug targeting. Proceedings of the Japan Academy. Series B, Physical and Biological Sciences, 88, 53-71.

Maiti, S., Krishnan, D., Barman, G., Ghosh, S. K., \& Laha, J. K. (2014). Antimicrobial activities of silver nanoparticles synthesized from Lycopersicon Esculentum extract. Journal of Analytical Science and Technology, 5, 40.

Maurer-Jones, M. A., Mousavi, M. P. S., Chen, L. D., Buhlmann, P., \& Haynes, C. L. (2013). Characterization of silver ion dissolution from silver nanoparticles using fluorous-phase ion-selective electrodes and assessment of resultant toxicity to Shewanella oneidensis. Chemical Science, 4, 2564-2572.

Mugabe, C., Azghani, A. O., \& Omri, A. (2006). Preparation and characterization of dehydration-rehydration vesicles loaded with aminoglycoside and macrolide antibiotics. International Journal of Pharmaceutics, 307, 244-250.

Mukherjee, S. G., O'Claonadh, N., Casey, A., \& Chambers, G. (2012). Comparative in vitro cytotoxicity study of silver nanoparticle on two mammalian cell lines. Toxicology In Vitro, 26, 238-251.

Murphy, A., Casey, A., Byrne, G., Chambers, G., \& Howe, O. (2016). Silver nanoparticles induce pro-inflammatory gene expression and inflammasome activation in human monocytes. Journal of Applied Toxicology, 36, 1311-1320. 
Murphy, A., Sheehy, K., Casey, A., \& Chambers, G. (2015). Potential of biofluid components to modify silver nanoparticle toxicity. Journal of Applied Toxicology, 35, 665-680.

Nehoff, H., Parayath, N. N., Domanovitch, L., Taurin, S., \& Greish, K. (2014) Nanomedicine for drug targeting: Strategies beyond the enhanced permeability and retention effect. International Journal of Nanomedicine, 9, 2539-2555.

Norbury, C. J., \& Zhivotovsky, B. (2004). DNA damage-induced apoptosis. Oncogene, 23, 2797-2808.

Nowrouzi, A., Meghrazi, K., Golmohammadi, T., Golestani, A., Ahmadian, S. Shafiezadeh, M., ... Amiri, A. N. (2010). Cytotoxicity of subtoxic AgNP in human hepatoma cell line (HepG2) after long-term exposure. Iranian Biomedical Journal, 14, 23-32.

Omar Zaki, S. S., Ibrahim, M. N., \& Katas, H. (2015). Particle size affects concentration-dependent cytotoxicity of chitosan nanoparticles towards mouse hematopoietic stem cells. Journal of Nanotechnology, 2015, 919658.

Park, E.-J., Yi, J., Kim, Y., Choi, K., \& Park, K. (2010). Silver nanoparticles induce cytotoxicity by a Trojan-horse type mechanism. Toxicology In Vitro, 24, 872-878.

Pramanik, S., Chatterjee, S., Saha, A., Devi, P. S., \& Suresh Kumar, G. (2016) Unraveling the interaction of silver nanoparticles with mammalian and bacterial DNA. Journal of Physical Chemistry B, 120, 5313-5324.

Quast, S. A., Berger, A., \& Eberle, J. (2013). ROS-dependent phosphorylation of Bax by wortmannin sensitizes melanoma cells for TRAILinduced apoptosis. Cell Death \& Disease, 4, e839.

Rampersad, S. N. (2012). Multiple applications of alamar blue as an indicator of metabolic function and cellular health in cell viability bioassays Sensors (Basel, Switzerland), 12, 12347-12360.

Samuel, U., \& Guggenbichler, J. P. (2004). Prevention of catheter-related infections: The potential of a new nano-silver impregnated catheter. International Journal of Antimicrobial Agents, 23(Suppl. 1), S75-S78.

Sercombe, L., Veerati, T., Moheimani, F., Wu, S. Y., Sood, A. K., \& Hua, S. (2015). Advances and challenges of liposome assisted drug delivery. Frontiers in Pharmacology, 6, 286.

Shannahan, J. H., Lai, X., Ke, P. C., Podila, R., Brown, J. M., \& Witzmann, F. A (2013). Silver nanoparticle protein corona composition in cell culture media. PLoS One, 8, e74001.

Silverman, J. A., Reynolds, L., \& Deitcher, S. R. (2013). Pharmacokinetics and pharmacodynamics of vincristine sulfate liposome injection (VSLI) in adults with acute lymphoblastic leukemia. Journal of Clinical Pharmacology, 53, 1139-1145.

Souto, G. D., Farhane, Z., Casey, A., Efeoglu, E., Mclntyre, J., \& Byrne, H. J. (2016). Evaluation of cytotoxicity profile and intracellular localisation of doxorubicin-loaded chitosan nanoparticles. Analytical and Bioanalytical Chemistry, 408, 5443-5455.

Su, C.-C., Lu, M.-C., Wang, S.-L., \& Huang, Y.-H. (2012). Ruthenium immobilized on $\mathrm{Al}_{2} \mathrm{O}_{3}$ pellets as a catalyst for hydrogen generation from hydrolysis and methanolysis of sodium borohydride. RSC Advances, 2, 2073-2079.

Tacar, O., Sriamornsak, P., \& Dass, C. R. (2013). Doxorubicin: An update on anticancer molecular action, toxicity and novel drug delivery systems. Journal of Pharmacy and Pharmacology, 65, 157-170.

Takeda, D. Y., \& Dutta, A. (2005). DNA replication and progression through S phase. Oncogene, 24, 2827-2843.

Vakkila, J., \& Lotze, M. T. (2004). Inflammation and necrosis promote tumour growth. Nature Reviews. Immunology, 4, 641-648.

Vance, M. E., Kuiken, T., Vejerano, E. P., McGinnis, S. P., Hochella, M. F. Jr. Rejeski, D., \& Hull, M. S. (2015). Nanotechnology in the real world Redeveloping the nanomaterial consumer products inventory. Beilstein Journal of Nanotechnology, 6, 1769-1780.

Wigginton, N. S., De Titta, A., Piccapietra, F., Dobias, J., Nesatyy, V. J. Suter, M. J., \& Bernier-Latmani, R. (2010). Binding of silver nanoparticles to bacterial proteins depends on surface modifications and inhibits enzymatic activity. Environmental Science \& Technology, 44, 2163-2168.

Willis, N., \& Rhind, N. (2009). Regulation of DNA replication by the S-phase DNA damage checkpoint. Cell Division, 4, 13.

Xing, H., Hwang, K., \& Lu, Y. (2016). Recent developments of liposomes as nanocarriers for theranostic applications. Theranostics, 6, 1336.

Xue, Y., Zhang, S., Huang, Y., Zhang, T., Liu, X., Hu, Y., ... Tang, M. (2012). Acute toxic effects and gender-related biokinetics of silver nanoparticles following an intravenous injection in mice. Journal of Applied Toxicology, 32, 890-899.

Yildirimer, L., Thanh, N. T., Loizidou, M., \& Seifalian, A. M. (2011). Toxicology and clinical potential of nanoparticles. Nano Today, 6, 585-607.

Zhang, X. F., Liu, Z. G., Shen, W., \& Gurunathan, S. (2016). Silver nanoparticles: Synthesis, characterization, properties, applications, and therapeutic approaches. International Journal of Molecular Sciences, 17, pii: E1534, 1534-1567.

Zhang, T., Wang, L., Chen, Q., \& Chen, C. (2014). Cytotoxic potential of silver nanoparticles. Yonsei Medical Journal, 55, 283-291.

\section{SUPPORTING INFORMATION}

Additional Supporting Information may be found online in the supporting information tab for this article.

How to cite this article: Yusuf A, Brophy A, Gorey B, Casey A. Liposomal encapsulation of silver nanoparticles enhances cytotoxicity and causes induction of reactive oxygen species-independent apoptosis. J Appl Toxicol. 2017;1-12. https://doi.org/ 10.1002/jat.3566 